\title{
Vá fyrir dyrum í heilbrigðiskerfinu
}

\section{Porbjörn Jónsson}

formaður Læknafélags Íslands

Höfundur er sérfræðingur í ónæmisfræði og blóðgjafarfræði og starfar á Landspítala.

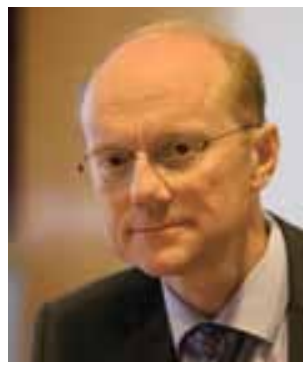

thorbjorn@lis.is

Læknar hafa boðað verkfall frá og með októberlokum. Fyrir rúmum premur áratugum sögðu stórir hópar lækna upp störfum til að knýja á um bætt kjör og stóðu aðgerðir læknanna pá í einn mánuð áður en samkomulag náðist við ríkisvaldið. Með breytingu á lögum um kjarasamninga opinberra starfsmanna árið 1986 fengu læknar formlega verkfallsrétt, pótt hann sé vissulega takmörkunum háður. Læknar hafa ekki kosið að beita pessum rétti sínum fyrr en nú.

Læknafélag Íslands býr yfir ýmiss konar upplýsingum um fjölda, búsetu og störf íslenskra lækna. Allar upplýsingar sem fyrir liggja sýna að nýliðun meðal peirra er algerlega ófullnægjandi. Strax í kjölfar efnahagshrunsins 2008 fækkaði læknum á Íslandi um allt að 10\% eins og ítrekað hefur komið fram í fjölmiðlum á undan-

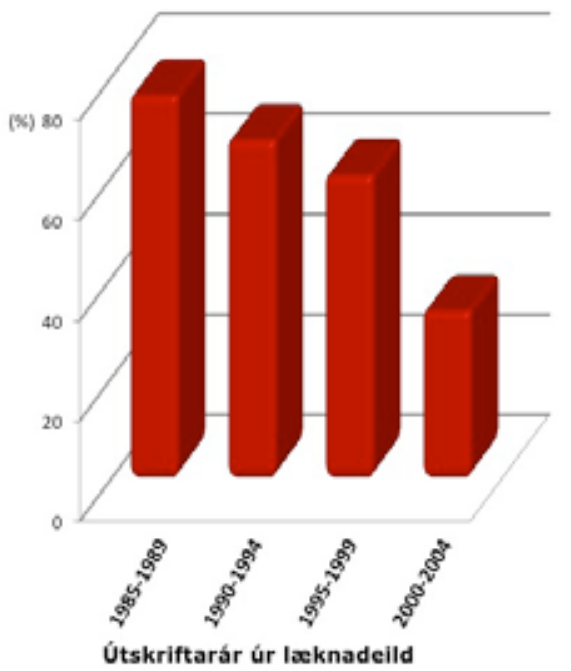

Mynd 1. Hlutfall lækna sem eru búsettir á Íslandi. förnum árum. Síðan hefur enn frekar sigið á ógæfuhliðina hvað varðar mönnun og par með vinnuálag hjá læknum. Yngri sérfræðilæknar sem lokið hafa sérnámi erlendis hafa ekki verið reiðubúnir að flytjast til Íslands í nægilega miklum mæli. Í pessu sambandi má jafnvel tala um hrun í nýliðun lækna (mynd 1). Kjarabarátta lækna nú snýst pess vegna ekki síst um pað að bæta kjör lækna nægjanlega til að pað takist að fá pennan hóp lækna til starfa á Íslandi í framtíðinni. Að gera laun lækna samkeppnishæfari í norrænu samhengi en pau eru nú. Ella blasir háski við heilbrigðiskerfinu.

Á fyrsta ársfjórðungi 2014 taldist Læknafélagi Íslands til að á landinu störfuðu um 1100 læknar og sýnir tafla I aldursdreifingu peirra. Раð sést að nærri 60\% lækna eru yfir fimmtugt og liðlega fjórðungur lækna er á sjötugsaldri. Meðalaldur sérfræðilækna árið 2013 var 55-56 ár og hefur hækkun meðalaldursins verið um hálft ár á ári hverju að undanförnu. Öllum hlýtur að vera ljóst hvert sú próun leiðir ef ekki tekst að spyrna við fótum. Samkvæmt félagaskrá Læknafélagsins hafa 330 læknar með lækningaleyfi flust af landi brott undanfarin 5 ár en einungis 140 flust aftur til landsins. Árlega flytja pví tæplega 40 fleiri læknar frá landinu en til pess. Ennfremur áætlar Læknafélagið að á næstu 5 árum fari meira en 130 læknar á eftirlaun, helmingi fleiri en fóru á eftirlaun undanfarin fimm ár.

Íslendingar hafa í heilbrigðismálum, eins og öðrum velferðarmálum, einkum borið sig saman við önnur Norðurlönd. Undanfarin ár höfum við verið að dragast aftur úr hvað fjölda lækna snertir. Á Norðurlöndunum eru nú að meðaltali 241 íbúi að baki hverjum starfandi lækni (218-271 eftir löndum). Á Íslandi eru hins vegar 296 íbúar á hvern lækni, sem pýðir að læknismönnun hér á landi er um 20\% lakari en á hinum Norðurlöndunum að meðaltali.

Fjöldi lækna og aldur peirra segir ekki nema hálfa sögu. Раð sem gerst hefur undanfarin ár er að læknar hafa í sívaxandi mæli minnkað við sig starfshlutfall hér á landi til pess að vinna erlendis, einkum á Norður- löndunum. Könnun sem Læknafélag Íslands gerði á högum 500 lækna veturinn 2012-2013 sýndi að yfir 20\% sérfræðilækna sem pá voru búsettir hér á landi störfuðu að hluta til, eða alfarið, erlendis. Pessi próun hófst við hrunið 2008 og hefur aukist ár frá ári. Meginástæða pess að læknar kjósa að starfa erlendis er að par bjóðast umtalsvert betri kjör en hér á landi, hærri laun og oftast líka færri vaktir og lengri frí.

Meginvandamál íslenska heilbrigðiskerfisins um pessar mundir er hve illa gengur að manna stöður lækna. Aðalástæða pess er að kjör hér á landi eru engan veginn samkeppnishæf við pað sem býðst í nágrannalöndum okkar. Úr pví parf að bæta og um pað snýst kjarabarátta lækna. Ef launakjörin batna ekki nægilega mikið til að fullmenntaðir yngri sérfræðilæknar búsettir erlendis vilji flytjast heim og pjóna í íslenska heilbrigðiskerfinu erum við í djúpstæðum vanda. Á honum verður að taka strax. Á síðustu árum hefur alvarlegt rof orðið í eðlilegri endurnýjun í læknastéttinni. Ennpá er hægt að stoppa í pau göt sem hafa myndast. Tíminn er pó að verða naumur. Pess vegna grípa læknar til verkfallsréttar síns. Brátt verður pað of seint.

\begin{tabular}{lc}
$\begin{array}{l}\text { Tafla I. Aldurssamsetning lækna á íslandi } \\
\text { i ársbyrjun 2014. }\end{array}$ & Hlutfall, \% \\
\hline Aldurshópur & 7 \\
\hline$<30$ ára & 8 \\
\hline $30-34$ ára & 5 \\
\hline $35-39$ ára & 11 \\
\hline $40-44$ ára & 12 \\
\hline $45-49$ ára & 16 \\
\hline $50-54$ ára & 14 \\
\hline $55-59$ ára & 15 \\
\hline $60-64$ ára & 12 \\
\hline $65-69$ ára
\end{tabular}

Imminent crisis in the Icelandic health care system

Thorbjörn Jónsson MD, PhD, Clinical Professor Specialist in Immunology and Transfusion Medicine Landspítali University Hospital, Reykjavík, Iceland 